\title{
Prediction of the Development of Depression in Patients with Autoimmune Thyroiditis and Hypothyroidism
}

\author{
Iryna Kamyshna*(iD, Larysa Pavlovych ${ }^{2}$, Alexandr M. Kamyshnyi ${ }^{3} \mathbb{D}$ \\ ${ }^{1}$ Department of Medical Rehabilitation, I. Horbachevsky Ternopil National Medical University, Ternopil, Ukraine; ${ }^{2}$ Department \\ of Clinical Immunology, Allergology and Endocrinology, HSEEU "Bukovinian State Medical University", Chernivtsi, Ukraine; \\ ${ }^{3}$ Department of Microbiology, Virology, and Immunology, I. Horbachevsky Ternopil National Medical University, Ternopil, Ukraine
}

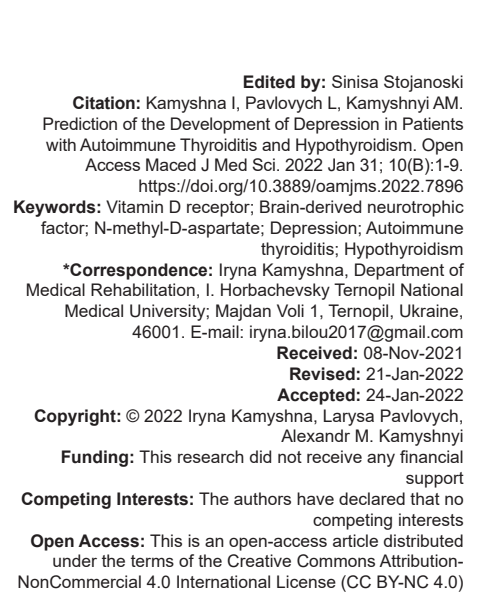

Abstract

BACKGROUND: Hypothyroidism is frequently accompanied by depression symptoms, whereas depression is considered the most common mental disorder.

AIM: It is crucial to analyze the associations of the brain neurotrophic factor (BDNF) gene polymorphism (rs6265) the VDR gene polymorphism (rs2228570), and the NMDA gene polymorphism (rs4880213) with the depression in patients with autoimmune thyroiditis and hypothyroidism in the Western Ukrainian population and predict the development of depressive disorders in these patients.

METHODS: The study involved a total of 153 patients with various forms of thyroid pathology. BDNF levels in the sera of the patients and healthy individuals were quantified using enzyme-linked immunosorbent assay with highly sensitive Human BDNF ELISA Kit (Elabscience®, United States, Catalog No: E-EL-H0010) on E.I.A. Reader Sirio S (Seac, Italy). Genotyping of the VDR (rs2228570), BDNF ( $r s 6265)$, and NMDA (rs4880213) gene polymorphism using TaqMan probes and TaqMan Genotyping Master Mix (4371355) on CFX96 TM Real-Time Polymerase chain reaction (PCR) Detection System (Bio-Rad Laboratories, Inc., USA). PCR for TaqMan genotyping was carried out according to the kit instructions (Applied Biosystems, USA). We used the Student's t-test, ANOVA, Pearson's Chi-square test, ROC-analysis, odds ratio test, relative odds ratio test. The odds ratio and $95 \%$ confidence interval were computed by binary logistic regression.

RESULTS: When comparing the presence of depression on the Hamilton scale, statistically significant differences were found depending on BDNF gene polymorphism (rs6265) $(p<0.001)$, and non-statistically noticeable differences were detected depending on the VDR gene polymorphism (rs2228570) and NMDA gene polymorphism (rs4880213). Our study revealed a marked inverse connection between depression and BDNF levels $(p<0.001)$ and a reverse moderate correlation between depression and fT4 $(p<0.001)$ and $25-\mathrm{OH}$ Vitamin D levels $(p<0.001)$. In addition, we identified a direct moderate correlation between pronounced levels of depression and thyroid-stimulating hormone (TSH) in the blood $(p<0.001)$

CONCLUSIONS: Indicators such as BDNF, TSH, fT4, anti-TPO, and 25-OH Vitamin D levels were found to be prognostically significant criteria for the risk of developing depression.

\section{Introduction}

The common reasons for hypothyroidism development are autoimmune disorders (Hashimoto's thyroiditis) and insufficient thyroid hormone production resulting from surgical removal of thyroid adenomas. Hypothyroidism is frequently accompanied by depression symptoms [1], [2]. The rate of depression moderately increases in patients with hypothyroidism [3].

Brain neurotrophic factor (BDNF) deficiency is considered one of the neurobiological mechanisms critically involved in depression [4], [5].

Various polymorphisms of Vitamin D receptors are considered significant in developing the risk for autoimmune thyroiditis (AIT) [6]. Recently, evidence has emerged that low Vitamin D levels are involved in the manifestations of depression and anxiety in the general population [7].
Autoimmune diseases of the thyroid gland affect the transcriptional activity of genes regulating neurogenesis and neurotrophins and can cause depression and neurological complications. Although, the neuronal $\mathrm{N}$-methyl-D-aspartate receptor is believed to play a key role in the pathophysiology of depression and neurological and mental illness correspondingly [8], [9].

One of the main directions of biomedical research today aimed to discover the role of genetic factors in the development of widespread multifactorial diseases [10] and the search for new targets for therapy [11]. Efficient methods for identifying hereditary predisposition to certain conditions are the analysis of transcriptome [12] and single nucleotide polymorphism [13], [14].

Our previous studies have proved that AIT and hypothyroidism can impair the transcription of genes engaged in neurogenesis [15], [16], the transmission 
of nerve impulses [17], and the regulation of the cell cycle [18]. Such changes in gene expression may influence the development of neurological complications associated with thyroid pathology [19], [20], [21], [22].

The work aims to analyze the associations of the BDNF gene polymorphism (rs6265), the VDR gene polymorphism (rs2228570), and the NMDA gene polymorphism (rs4880213) with the depression in patients with AIT and hypothyroidism in the Western Ukrainian population and predict the development of depressive disorders in these patients.

\section{Materials and Methods}

Our research was conducted in Bukovinian State Medical University, Chernivtsi Regional Endocrinology Center, and I. Horbachevsky Ternopil National Medical University, Ukraine. The study included a total of 153 patients with different types of thyroid pathology. The subjects were distributed into three groups. Group $1(n=16)$ comprised patients with postoperative hypothyroidism (PO); Group 2 ( $n=65)$ included patients with hypothyroidism $(\mathrm{H})$ caused by AIT, and Group $3(n=72)$ included patients with both AIT and elevated serum antibodies anti-thyroglobulin (anti-Tg) and anti-thyroid peroxidase (anti-TPO). Twenty-five healthy individuals were randomly selected as a control group without adjusting for age or sex.

\section{Ethical approval}

The study fully ensured standards described in the 1975 Helsinki Declaration of Human Rights (amended in 2008). The participants completed and signed a written informed consent before enrolling voluntarily in the research. The Ethics Committee of the HSEEU "Bukovinian State Medical University," I. Horbachevsky Ternopil National Medical University, and Chernivtsi Regional Endocrinology Center, Ukraine, have approved this study (approval ID: 11-07.11.2017).

To diagnose hypothyroidism, we were guided by recommendations required by the American Association of Clinical Endocrinologists 2012. The corresponding clinical features were considered when verifying AIT, namely the results of a sonogram of the thyroid gland (reduced echogenicity) and circulating antibodies to thyroid antigens, anti-TPO, and anti-TG were detected [23].

Blood samples from patients and controls were taken in the morning (8-10 am) after a night fast. Using STAT FAX303/Plus analyzer (Awareness Technology Inc, USA), we determined levels of thyroxine (fT4, normal range $6.0-13.0 \mathrm{pmol} / \mathrm{L}$ for males and 7.0-13.5 $\mathrm{pmol} / \mathrm{L}$ for females), thyroid-stimulating hormone (TSH, normal range $0.3-4.0 \mathrm{mIU} / \mathrm{mL}$ ), anti-thyroid peroxidase (anti-TPO, normal range $0-30 \mathrm{IU} / \mathrm{mL}$ ), and antithyroglobulin (anti-TG, normal range 0-65 $\mathrm{IU} / \mathrm{mL}$ ) in each individual who participated in the study.

Study exclusion criteria were the following: Less than 18 years of age, malignancy, inflammation resulting from rheumatic diseases or acute/chronic infection, diabetes mellitus, vascular, chronic diseases of liver and kidneys, and pregnancy. Individuals administering drugs that could influence thyroid function were also ruled out from the study.

We identified the severity of depression levels using the Hamilton Depression Rating Scale (HDRS), which is reliable for depression assessment. Due to the HDRS, scores of 0-7, 8-13, 14-18, 19-23, and 23-53 are regarded as normal, mild, medium, severe, and very severe, correspondingly [24].

To quantify BDNF levels in the sera of the patients and healthy individuals, we used enzymelinked immunosorbent assay with highly sensitive Human BDNF (Brain-Derived Neurotrophic Factor) ELISA Kit (Elabscience $®$, United States, Catalog No: E-EL-H0010) on E.I.A. Reader Sirio S (Seac, Italy).

When determining 25-OH Vitamin D levels in the serum of the patients and healthy individuals, we applied the ELISA using the 25-OH Vitamin D Total (Vit D-Direct) Test System ELISA Kit (Monobind Inc.®, United States, Product Code: 9425-300) on E.I.A. Reader Sirio S (Seac, Italy).

\section{Genotyping of the VDR (rs2228570), BDNF (rs6265), and NMDA (rs4880213) Gene Polymorphism}

\section{DNA isolation}

When collecting venous blood, we used a sterile Vacutainer and stabilized it with K2EDTA. To isolate Total DNA from peripheral blood, we applied PREP-RAPID-GENETICS DNA Extraction Kit (DNATECHNOLOGY, Russian Federation), adhering to the manufacturer's instructions.

\section{DNA amplification and genotyping}

The samples were genotyped by TaqMan probes and TaqMan Genotyping Master Mix (4371355) on CFX96 ${ }^{\mathrm{TM}}$ Real-Time polymerase chain reaction (PCR) Detection System (Bio-Rad Laboratories, Inc., USA). PCR for TaqMan genotyping was conducted due to the kit instructions (Applied Biosystems, USA). TaqMan Genotyping Master Mix contains DNA polymerase AmpliTaq Gold®, dNTPs, reference dye ROX $^{\mathrm{TM}}$, and buffer ingredients. TaqMan probes are target-specific oligonucleotides with reporter dyes attached to the 5' end of each probe: (VIC $\AA$ dye on the 5 ' end of the Allele 1 probe and 6FAM TM dye on 
Table 1: Demographic, clinical, and biochemical characteristics of study participants

\begin{tabular}{|c|c|c|c|c|}
\hline Variable & Control group $(n=25)$ & $\begin{array}{l}\text { Patients with postoperative } \\
\text { hypothyroidism (PO, } n=16)\end{array}$ & $\begin{array}{l}\text { Patients with AIT-induced hypothyroidism } \\
\text { (AIT with hypothyroidism, } \mathrm{n}=65 \text { ) }\end{array}$ & $\begin{array}{l}\text { Patients with AIT and elevated anti-Tg } \\
\text { and anti-TPO antibodies (AIT, } n=72 \text { ) }\end{array}$ \\
\hline Age (years) & $46.08 \pm 14.58$ & $47.30 \pm 12.27$ & $46.72 \pm 15.49$ & $45.02 \pm 13.65$ \\
\hline fT4 (pmol/L) & $8.91 \pm 0.97$ & $3.44 \pm 0.31$ & $4.13 \pm 0.52$ & $8.51 \pm 0.82$ \\
\hline $\mathrm{TSH}(\mathrm{mlU} / \mathrm{mL})$ & $2.67 \pm 0.52$ & $8.61 \pm 0.84$ & $7.09 \pm 0.50$ & $2.38 \pm 0.62$ \\
\hline anti-TPO (IU/mL) & $34.04 \pm 3.70$ & $36.13 \pm 2.78$ & $380.62 \pm 73.42$ & $330.36 \pm 50.23$ \\
\hline anti-TG (IU/mL) & $15.32 \pm 1.97$ & $15.50 \pm 1.90$ & $32.97 \pm 4.27$ & $36.38 \pm 7.70$ \\
\hline Current dose of L-thyroxine ( $\mu \mathrm{g} /$ day $)$ & None & $110.95 \pm 5.25$ & $88.46 \pm 1.55$ & None \\
\hline $25-\mathrm{OH}$ Vitamin D ng/mL & $39.2 \pm 6.58$ & $20.69 \pm 3.09(p<0.001)$ & $19.08 \pm 3.144(p<0.001)$ & $21.48 \pm 2.83(p<0.001)$ \\
\hline BDNF (pg/ml) & $1037.8 \pm 361.83$ & $310.19 \pm 112.84(p<0.001)$ & $329.34 \pm 312.57(p<0.001)$ & $1031.34 \pm 385(p=0.95)$ \\
\hline
\end{tabular}

the 5' end of the Allele 2 probe), and a non-fluorescent quencher the 3' end of the probe. Genomic DNA was intensified in a $10 \mu \mathrm{L}$ reaction mix comprising genomic DNA, forward and reverse primers, fluorescent probes, and TaqMan Genotyping Master Mix. Genotyping of the samples conducted on the CFX-Manager ${ }^{\mathrm{TM}}$ software using allelic discrimination assays based on the magnitude of relative fluorescence units.

\section{Statistical analysis}

We used the Student's t-test, ANOVA, Pearson's Chi-square test, ROC-analysis, odds ratio test, relative odds ratio test, and equality 0 correlation test to determine the difference between groups. The odds ratio and $95 \%$ confidence interval $(\mathrm{Cl})$ were computed by binary logistic regression, where $p<0.05$ were regarded as a statistically significant difference between the two groups (Statsoft Statistica v.12.0).

\section{Results}

In our present study, we inspected the relationship between BDNF gene polymorphism (rs6265), VDR gene polymorphism (rs2228570), and NMDA Gene Polymorphism (rs4880213) with depression in patients with AIT and hypothyroidism in the population of Western Ukraine.

The demographic, clinical, and biochemical characteristics of the participants are displayed in Table 1.

When analyzing the data on the Hamilton scale, depression was detected in all patients with post-operative hypothyroidism and $95.4 \%$ of patients with AIT with hypothyroidism. In patients with AIT, depressive disorders were observed in $59.7 \%$ of patients (Figure 1).
Mild depressive disorder was observed in $26.2 \%$ of patients with AIT with hypothyroidism and $36.1 \%$ of patients with AIT. Moderate depressive disorder was found in all patients with $\mathrm{PO}$, in $69.2 \%$ of patients with AIT-induced hypothyroidism and $23.6 \%$ of patients with AIT. We detected no severe or highly severe depressive disorder in the examined patients (Table 2).

We performed the analysis of the presence of depression on Hamilton conditioning on SNP.

According to Table 3, when comparing the presence of depression on the Hamilton scale, statistically significant differences were found depending on BDNF gene polymorphism (rs6265) $(p<0.001)$. Due to the presence of depression on the Hamilton scale, depending on the VDR gene polymorphism (rs2228570) and NMDA gene polymorphism (rs4880213), non-statistically noticeable differences were detected $(p=0.246, p=$ 0.633, respectively) (Pearson's Chi-square test).

When comparing the level of depression on the Hamilton scale (Table 4), there was a probable increase in scores in the study group in carriers of all genotypes compared with the control group. Thus, there was a possible increase in the number of scores by 2.42 -fold in carriers of the CC genotype, 2.32-fold in carriers of the CT genotype, and 2.21 folds in carriers of the TT genotype compared to the control.

A study of Depression Levels (in scores) in patients with different thyroid pathology depending on the rs6265 polymorphism genotype (Table 4) showed the highest scores on the Hamilton Depression Scale in TT genotype carriers in the experimental group of patients compared to the CC genotype carriers. In a like manner, in groups of patients with TT genotype, the Depression Levels (in scores) were significantly higher (AIT with hypothyroidism: 1.26-fold; and AIT: 2.56-fold) compared to patients with CC genotype. Such results indicate that the TT genotype carriers have higher rates of depression on the Hamilton scale, which the thyroid gland pathology can further exacerbate.

Table 2: Analysis of the presence of depression on the Hamilton scale in groups of subjects

\begin{tabular}{|c|c|c|c|c|c|c|}
\hline \multirow[t]{2}{*}{ Variable } & \multirow[t]{2}{*}{ Categories } & \multicolumn{4}{|c|}{ Groups of subjects } & \multirow[t]{2}{*}{$\mathrm{p}$} \\
\hline & & Control & PO & AIT with $\mathrm{H}$ & AIT & \\
\hline $\begin{array}{l}\text { Presence of } \\
\text { depression on } \\
\text { hamilton rating } \\
\text { scale }\end{array}$ & $\begin{array}{l}\text { Normal } \\
\text { Mild depressive disorder } \\
\text { Depressive disorder of } \\
\text { moderate severity }\end{array}$ & $\begin{array}{l}24(96.0) \\
1(4.0) \\
0(0.0)\end{array}$ & $\begin{array}{l}0(0.0) \\
0(0.0) \\
16(100.0)\end{array}$ & $\begin{array}{l}3(4.6) \\
17(26.2) \\
45(69.2)\end{array}$ & $\begin{array}{l}29(40.3) \\
26(36.1) \\
17(23.6)\end{array}$ & $\begin{array}{l}\mathrm{p}_{\text {Control - PO }}<0.001 \\
\mathrm{p}_{\text {Control-AIT with H }}<0.001 \\
\mathrm{p}_{\text {Control -AIT }}<0.001 \\
\mathrm{p}_{\mathrm{PO} \text {-AIT with H }}=0.038 \\
\mathrm{p}_{\text {PO-AIT }}<0.001 \\
\mathrm{p}_{\text {AIT with H-AIT }}<0.001\end{array}$ \\
\hline
\end{tabular}


Table 3: Analysis of the presence of depression on hamilton conditioning on SNP

\begin{tabular}{|c|c|c|c|c|c|}
\hline \multirow[t]{2}{*}{ Variables } & \multirow[t]{2}{*}{ Categories } & \multicolumn{3}{|c|}{ Presence of depression on Hamilton Rating Scale } & \multirow[t]{2}{*}{$\mathrm{p}$} \\
\hline & & Normal & Mild depressive disorder & Depressive disorder of moderate severity & \\
\hline \multirow[t]{3}{*}{ BDNF gene polymorphism (rs6265) } & $\mathrm{CC}$ & $49(40.5)$ & $38(31.4)$ & $34(28.1)$ & \multirow{6}{*}{$\begin{array}{l}\mathrm{p}<0.001^{*} \\
\mathrm{p}_{\mathrm{CC}-\mathrm{CT}}<0.001 \\
\mathrm{p}_{\mathrm{CC}-\mathrm{TT}}=0.001 \\
0.246\end{array}$} \\
\hline & СT & $6(13.3)$ & $5(11.1)$ & $34(75.6)$ & \\
\hline & TT & $1(8.3)$ & $1(8.3)$ & $10(83.3)$ & \\
\hline \multirow[t]{3}{*}{ VDR gene polymorphism (rs2228570) } & AA & $25(36.8)$ & $13(19.1)$ & $30(44.1)$ & \\
\hline & AG & $21(28.8)$ & $17(23.3)$ & $35(47.9)$ & \\
\hline & GG & $10(27.0)$ & $14(37.8)$ & $13(35.1)$ & \\
\hline \multirow[t]{3}{*}{ NMDA gene polymorphism (rs4880213) } & $\mathrm{CC}$ & $15(27.8)$ & $17(31.5)$ & $22(40.7)$ & \multirow[t]{3}{*}{0.633} \\
\hline & СT & $30(35.3)$ & $18(21.2)$ & $37(43.5)$ & \\
\hline & TT & $11(28.2)$ & $9(23.1)$ & $19(48.7)$ & \\
\hline
\end{tabular}

${ }^{*}$ Differences are statistically significant $(p<0.05)$.

Table 4: Indices of the level of depression on the Hamilton scale (in scores) in patients with different thyroid pathology depending on the genotype variants by gene polymorphism

\begin{tabular}{|c|c|c|c|c|c|c|}
\hline \multicolumn{7}{|c|}{ BDNF gene polymorphism (rs6265) (M $\pm \mathrm{m})$} \\
\hline Variables & CC & CT & TT & P5 & P6 & P7 \\
\hline Control group $(n=25)$ & $4.24 \pm 0.75(17)$ & $6.67 \pm 0.516(6)$ & $7.5 \pm 0.7(2)$ & $<0.001$ & 0.066 & 0.065 \\
\hline Study group $(n=153)$ & $10.26 \pm 4.63(104)$ & $15.51 \pm 1.57(39)$ & $16.6 \pm 1.43(10)$ & $<0.001$ & $<0.001$ & $<0.001$ \\
\hline P1 & $<0.001$ & $<0.001$ & $<0.001$ & & & \\
\hline$P O(n=16)$ & $16 \pm 1.07(8)$ & $14.83 \pm 0.75(6)$ & $14.5 \pm 0.7(2)$ & 0.033 & 0.119 & 0.117 \\
\hline P1 & $<0.001$ & $<0.001$ & 0.01005 & & & \\
\hline P2 & $<0.001$ & $<0.0034$ & 0.1154 & & & \\
\hline AIT with hypothyroidism $(n=65)$ & $2.93 \pm 3.4(46)$ & $16.31 \pm 1.14(16)$ & $16.33 \pm 1.15(3)$ & $<0.001$ & 0.0103 & 0.01 \\
\hline P1 & $<0.001$ & $<0.001$ & 0.0018 & & & \\
\hline P3 & $<0.001$ & 0.0196 & 0.188 & & & \\
\hline AIT $(n=72)$ & $6.88 \pm 3.25(50)$ & $15 \pm 1.84(17)$ & $17.6 \pm 0.55(5)$ & $<0.001$ & $<0.001$ & $<0.001$ \\
\hline P1 & $<0.001$ & $<0.001$ & 0.0094 & & & \\
\hline P4 & $<0.001$ & 0.75 & 0.053 & & & \\
\hline
\end{tabular}

and AIT groups. P5 - Student's t between CC and CT genotypes. P6 - Student's t between CC and TT genotypes. P7 - Student's t between CT and TT genotypes. AIT: Autoimmune thyroiditis.

In patients with postoperative hypothyroidism, the depression indices on the Hamilton scale were high in carriers of all three genotypes and, probably, did not differ from each other.

At the same time, in patients with AIT, the Hamilton rating scale for depression indicate that individuals with TT genotypes had significantly higher scores on the depression scale compared to those with CT and CC genotypes.

Correlation analysis of the relationship between the levels of hormones and Depression was conducted (Table 5).

Analysis of the correlation between depression and the levels of TSH, fT4, anti-TG, and anti-TPO antibodies, 25-OH Vitamin D, and BDNF levels exhibits a marked inverse connection between depression and BDNF levels $(p<0.001)$ and a reverse moderate correlation between depression and fT4 $(p<0.001)$ and $25-\mathrm{OH}$ Vitamin $D$ levels $(p<0.001)$. In addition, we identified a

Table 5: Results of the correlation analysis of the association between the levels of hormones and depression

\begin{tabular}{llll}
\hline Variables & \multicolumn{2}{l}{ Correlation characteristics } & \\
\cline { 2 - 4 } & & $\begin{array}{l}\text { The strength of the association was } \\
\text { assessed using the Chaddock scale }\end{array}$ & $\mathrm{p}$ \\
\hline BDNF - Depression & -0.612 & Close correlation & $<0.001^{*}$ \\
TSH - Depression & 0.434 & Moderate correlation & $<0.001^{*}$ \\
fT4 - Depression & -0.442 & Moderate correlation & $<0.001^{*}$ \\
anti-TPO - Depression & 0.284 & Weak correlation & $<0.001^{*}$ \\
anti-TG - Depression & 0.156 & Weak correlation & $0.048^{*}$ \\
25-OH Vitamin D - Depression & -0.376 & Moderate correlation & $<0.001^{*}$ \\
\hline${ }^{*}$ Differences are statistically significant $(\mathrm{p}<0.05)$. TSH: Thyroid-stimulating hormone. &
\end{tabular}

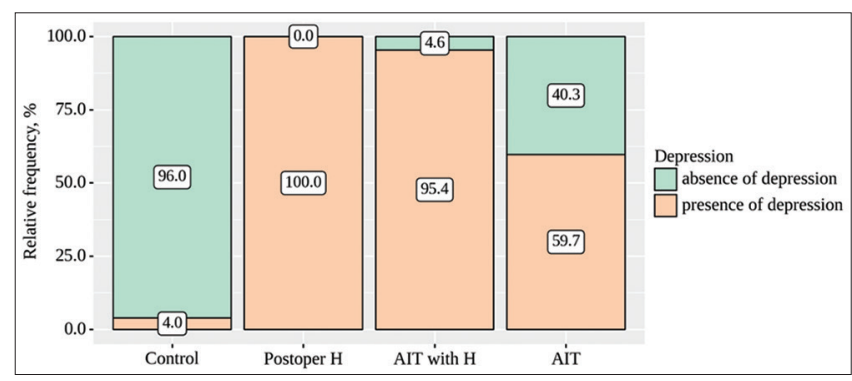

Figure 1: Analysis of depression conditioning on the Hamilton scale in Groups of subjects

direct moderate correlation between pronounced levels of depression and TSH in the blood ( $p<$ 0.001 ) and a weak direct relationship between depression and anti-TPO $(p<0.001)$ and anti-TG $(p=0.048)$.

The observed dependence of depression from BDNF is described by a linear regression equation:

With 1 increase of BDNF -0.008 change of depression should be awaited. Due to the coefficient for determination $\mathrm{R}^{2}$ of the resulting model, $54.4 \%$ of the observed variance of depression was explicated (Figure 2).

According to Table 6, when comparing the "Depression" indices depending on the "BDNF Level," we detected significant differences ( $p=0.025$, $\mathrm{p}<0.001$, respectively). 
Table 6: Analysis of depression conditioning on BDNF and 25-OH Vitamin D levels

\begin{tabular}{|c|c|c|c|c|}
\hline \multirow[t]{2}{*}{ Variables } & \multirow[t]{2}{*}{ Categories } & \multicolumn{2}{|l|}{ Depression } & \multirow{2}{*}{$p$} \\
\hline & & $\begin{array}{l}\text { Absence of } \\
\text { depression }\end{array}$ & $\begin{array}{l}\text { Presence of } \\
\text { depression }\end{array}$ & \\
\hline \multirow[t]{2}{*}{ BDNF Level } & Normal level & $19(43.2)$ & $25(56.8)$ & \multirow[t]{2}{*}{$p=0.025^{\star}$} \\
\hline & Decrease level & $6(18.8)$ & $26(81.2)$ & \\
\hline \multirow[t]{4}{*}{ 25-OH Vitamin D } & Normal level & $24(96.0)$ & $1(4.0)$ & \multirow{4}{*}{$\begin{array}{l}\mathrm{p} 1<0.001 \\
\mathrm{p} 2<0.001 \\
\mathrm{p} 3=0.015\end{array}$} \\
\hline & Vitamin $\mathrm{D}<20 \mathrm{ng} / \mathrm{mL}$ (Vitamin & $10(13.0)$ & $67(87.0)$ & \\
\hline & D deficiency) & & & \\
\hline & $\begin{array}{l}\text { Vitamin } \mathrm{D}=20-30 \mathrm{ng} / \mathrm{mL} \\
\text { (Suboptimal Vitamin D } \\
\text { availability) }\end{array}$ & $22(28.9)$ & $54(71.1)$ & \\
\hline
\end{tabular}

The probability of the presence of depression in the group with a decreased level of BDNF was 3.293-fold higher than in the normal level group, the chance differences were statistically significant $(95 \%$ Cl: 1.130-9.597).

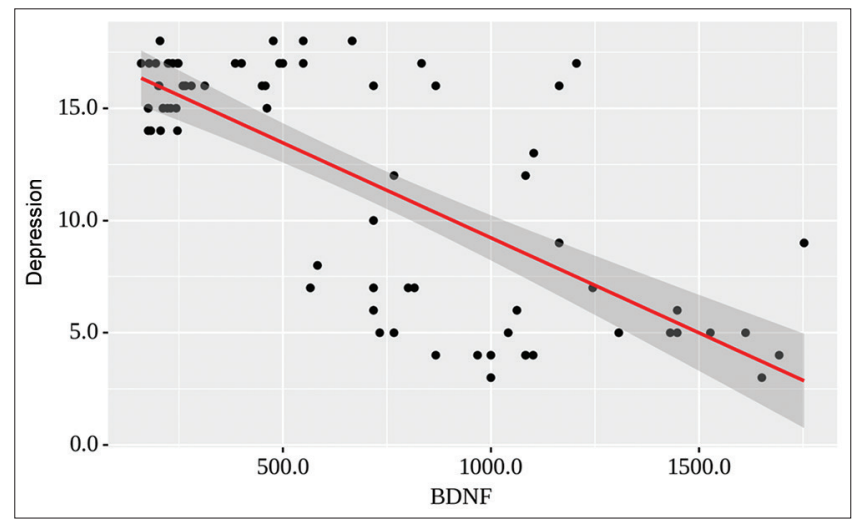

Figure 2: Regression line characterizing the dependence of depression from brain neurotrophic factor

We conducted a study of the prognostic value of plasma levels of a number of hormones as potential markers of depression. The displayed curve was obtained during the estimation of the dependence of detecting the presence of depression conditioning on BDNF using ROC analysis (Figure 3).

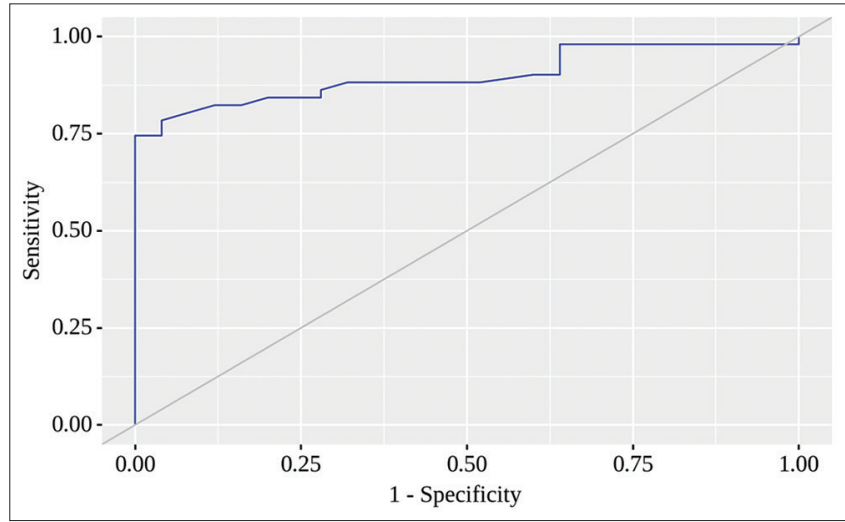

Figure 3: ROC-curve characterizing the dependence of the probability depression on brain neurotrophic factor levels

The area under the ROC curve comprised $0.900 \pm 0.044$ with $95 \% \mathrm{Cl}: 0.814-0.985$. The resulting model was statistically significant $(p<0.001)$.

The cut-off value of BDNF which corresponds to the highest Youden's $\mathrm{J}$ statistic is 566.240. If BDNF was less than or equal to this value, the presence of depression was predicted. The sensitivity and specificity of the method were $74.5 \%$ and $100.0 \%$, respectively.

In addition to the BDNF level, indicators such as TSH, fT4, anti-TPO, and 25-OH Vitamin D levels were found to be prognostically significant criteria for the risk of developing depression.

Therefore, the estimation of the dependence of detecting the presence of depression conditioning on TSH using ROC analysis revealed that the area under the ROC curve comprised $0.770 \pm 0.037$ with $95 \%$ Cl: 0.697-0.844. The resulting model was statistically significant $(p<0.001)$. The cut-off value of TSH which corresponds to the highest Youden's $\mathrm{J}$ statistic is 6.300. If TSH was greater than or equal to this value, the presence of depression was predicted. The sensitivity and specificity of the method were $65.0 \%$ and $95.6 \%$, respectively.

The analysis of the dependence of detecting the presence of depression conditioning on fT4 using ROC analysis revealed that the area under the ROC curve comprised $0.797 \pm 0.043$ with $95 \% \mathrm{Cl}$ : 0.713 0.881 . The resulting model was statistically significant $(p<0.001)$. The cut-off value of fT4 which corresponds to the highest Youden's J statistic is 7.200. If fT4 was less than or equal to this value, the presence of depression was predicted. The sensitivity and specificity of the method were $68.4 \%$ and $93.3 \%$, respectively.

We found that the area under the ROC curve of the dependence of depression conditioning on anti-TPO using ROC analysis comprised $0.745 \pm 0.040$ with $95 \%$ Cl: $0.667-0.822$. The resulting model was statistically significant $(p<0.001)$. The cut-off value of anti-TPO which corresponds to the highest Youden's $\mathrm{J}$ statistic is 42.000. If АТПО was greater than or equal to this value, the presence of depression was predicted. The sensitivity and specificity of the method were $86.3 \%$ and $53.3 \%$, respectively.

The following curve was obtained when estimating the dependence of detecting the presence of depression conditioning on 25-OH Vitamin D using ROC analysis (Figure 4).

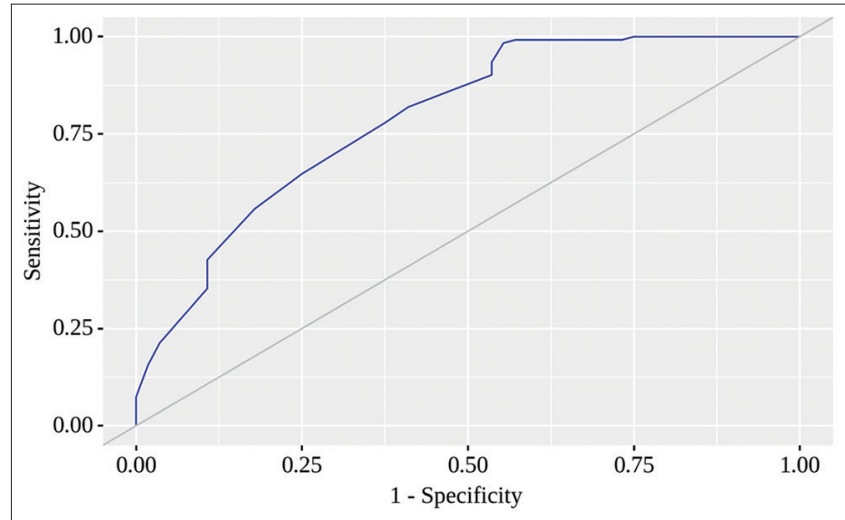

Figure 4: ROC-curve characterizing the dependence of the probability of depression on 25-OH Vitamin D

The area under the ROC curve comprised $0.791 \pm 0.039$ with $95 \% \mathrm{Cl}: 0.714-0.868$. The resulting model was statistically significant $(p<0.001)$. 
The cut-off value of $25-\mathrm{OH}$ Vitamin D which corresponds to the highest Youden's $\mathrm{J}$ statistic is 28.000. If $25-\mathrm{OH}$ Vitamin $\mathrm{D}$ was less than or equal to this value, the presence of depression was predicted. The sensitivity and specificity of the method were $98.4 \%$ and $44.6 \%$, respectively.

The depression dependency on quantitative variables was assessed by multiple linear regressions (Table 7). Simple or multivariate linear regression enabled the development of predictive modeling of the quantitative variable conditioning on other quantitative variables.

Table 7: Analysis of depression conditioning on BDNF, 25-OH Vitamin D

\begin{tabular}{lllll}
\hline & $\mathrm{B}$ & Std. error & $\mathrm{T}$ & $\mathrm{P}$ \\
\hline Intercept & 23.792 & 0.976 & 24.372 & $<0.001^{*}$ \\
BDNF & -0.006 & 0.001 & -8.450 & $<0.001^{*}$ \\
25-OH Vitamin D & -0.317 & 0.042 & -7.578 & $<0.001^{*}$ \\
\hline "Differences are statistically significant $(\mathrm{p}<0.05)$. & & &
\end{tabular}

The observed association of depression with BDNF, 25-OH Vitamin D is presented by a linear regression equation:

$$
\mathrm{X}_{25-\mathrm{OH} \text { Vitamin } \mathrm{D}} \mathrm{Y}_{\text {depression }}=23.792-0.006 \times \mathrm{X}_{\mathrm{BDNF}}-0.317 \times
$$

With a 1 increase of BDNF, 0.006 of depression should be expected. With a 1 increase of $25-\mathrm{OH}$ Vitamin D, 0.317 of depression should be expected.

The resulting regression model is characterized by a correlation coefficient $r_{x y}=0.9$, which corresponds to the Strong relationship on the Chaddock scale. The model was statistically significant $(p<0.001)$. Based on the value of the coefficient of determination $\mathrm{R}^{2}$, the model accounts for $74.5 \%$ of depression variance.

\section{Discussion}

Thyroid dysfunctions are commonly related to impaired brain function [25]. The connection of thyroid hormone deficiency with anxiety and depression has been addressed extensively in different reliable studies [2], [3], [26].

An evidence-based study (with 13,000 subjects enrolled) evaluating this issue [27] detected a correlation between increased TSH levels and depression, even with TSH levels within the standard laboratory range. In particular, the depression rate was twice as high in women with $\mathrm{TSH}$ levels above $2.3 \mathrm{mIU} / \mathrm{mL}$, indicating again that the optimal TSH level is well below $4 \mathrm{mlU} / \mathrm{mL}$. It is of interest that this current study demonstrates a positive correlation and statistical significance between T4 and TSH levels and depression symptoms.

In our study when analyzing the data on the Hamilton scale, depression was detected in all patients with postoperative hypothyroidism and $95.4 \%$ of patients with AIT with hypothyroidism. In patients with AIT, depressive disorders were observed in $59.7 \%$ of patients. This outcome is similar to a large study that enrolled over 1000 women with thyroid disease taking T4 [28], which showed that higher TSH levels were attributive to more depression and anxiety. Two other studies report no relationship between TSH levels and depression symptoms in patients with different types of thyroid diseases [29].

In addition, another study found that untreated hypothyroidism is correlated with an increase in the Beck Depression Inventory score [3].

The current neurotrophic hypothesis claims that depression contributes to the lower expression of neurotrophins and aberrant neurogenesis in brain areas [30]. BDNF is an essential neuronal growth factor in the brain, regulating neurogenesis, neuronal maturation, survival, and synaptic plasticity. Low levels of BDNF have been noticed in the brain of depressed patients [31]. It has also advocated that depression is associated with neuronal cell loss in specific brain areas such as the hippocampus and cerebral cortex [32]

A decrease in hippocampus volumes in depressed patients proves the hypothesis that depression is connected with a reduced level of neurotrophic factors that regulate neuronal plasticity in the adult brain [33].

Our study revealed that the probability of the presence of depression in the group with a decreased level of BDNF was 3.293-fold higher than in the normal level group; the chance differences were statistically significant (95\% Cl: 1.130-9.597).

Regarding the critical role of BDNF in the brain, a variety of genetic studies have concentrated on the effect of BDNF polymorphism on brain function and behavior in healthy people, in addition to pathological conditions, especially neuropsychiatric disorders [34].

Rs6265, a common BDNF SNP in humans, causes an amino acid change from valine to methionine at codon 66 (Val66Met), which is located in the BDNF prodomain. The Val66Met polymorphism has been demonstrated the interference with BDNF trafficking and lower its secretion [35]. Some respective studies have identified an association between the Val66Met polymorphism and a decrease in hippocampal and prefrontal gray matter volumes, causing abnormal hippocampal activity, impaired cognitive function, and decreased memory and executive function [36].

In our study, when comparing the level of depression on the Hamilton scale (in scores) in patients with different thyroid pathology depending on the rs6265 polymorphism genotype showed, the highest scores in TT genotype carriers in the experimental group of patients compared to the CT and CC genotypes carriers. 
Studies reported that the rs6265 T allele is associated with reduced concentrations of blood serum BDNF in healthy German subjects [37]. Mice homozygous for the $T$ allele showed a decrease in basal BDNF levels in the hippocampus. Administration of antidepressant fluoxetine could not regulate these levels [38]. As opposed to another study that suggested that the Met allele of the BDNF Val66Met polymorphism can be related to an increase in BDNF serum concentrations [39].

Besides, the rs6265 $\mathrm{T}$ allele is related to low serum BDNF levels. We suppose that against the background of thyroid pathology, genetic predisposition played quite an essential role in depression.

During the estimation of the dependence of detecting, the presence of depression conditioning on BDNF using ROC analysis the area under the ROC curve comprised $0.900 \pm 0.044$ with $95 \% \mathrm{Cl}: 0.814-0.985$. The resulting model was statistically significant $(p<0.001)$.

The cut-off value of BDNF which corresponds to the highest Youden's $\mathrm{J}$ statistic is 566.240. If BDNF was less than or equal to this value, the presence of depression was predicted. The sensitivity and specificity of the method were $74.5 \%$ and $100.0 \%$, respectively.

Recentstudies profoundly described a correlation between a 25(OH)D deficiency and depressive disorders and symptoms [7]. Hoogendijk et al., in a cohort study of 1200 individuals older than 65 years, noticed significantly reduced $25(\mathrm{OH}) \mathrm{D}$ levels of $14 \%$ and $14 \%$ in patients with minor and major depression, correspondingly, when compared to the healthy controls, even after matching for the age, sex, body mass index, smoking status, and several chronic conditions [40].

In our study, we identified a marked inverse connection between depression and BDNF levels $(p<0.001)$ and a reverse moderate correlation between depression and fT4 $(p<0.001)$ and $25-\mathrm{OH}$ Vitamin $D$ levels $(p<0.001)$. In addition, we found a direct moderate correlation between pronounced levels of depression and TSH in the blood $(p<0.001)$ and a weak direct relationship between depression and antiTPO $(p<0.001)$ and anti-TG $(p=0.048)$.

Present studies have also reported about relationship between Vitamin $D$ deficiency and thyroid dysfunction [41]. Low 25(OH)D levels have been observed in patients with hypothyroidism and Grave's disease [42].

Carta et al. have found a connection between having a lifelong diagnosis of mood or anxiety disorder and Hashimoto's euthyroid disease [43]. Another study also exhibited an elevated frequency and higher severity of depression in patients with chronic AIT and normal thyroid function [44].

Thus, there may be an association between thyroid autoimmunity, changes in the immune system, and changes in neurotransmitters that could lead to depressive disorders, impact the course of the disease and influence the response to antidepressant treatment.

\section{Conclusions}

This study traces and proves a link between AIT and hypothyroidism and depressive disorders. Patients with AIT and hypothyroidism show an increased chance of developing symptoms of depression or being diagnosed with depressive disorders. The outcomes of this study are essential for patients with AIT and could contribute not only to early treatment choices but psychotherapeutic treatment for organic disease.

Ongoing and prospective long-term randomized controlled trials are necessary to gain insight into the effectiveness and safety of Vitamin D as a therapeutic agent for these thyroid disorders and the prevention and treatment of neurological complications.

\section{Acknowledgments}

The approval for this study was obtained from the Ethics Committee of the Bukovinian State Medical University, Chernivtsi Regional Endocrinology Center, and I. Horbachevsky Ternopil National Medical University, Ukraine (approval ID: 11-07.11.2017.

Our study was conducted according to the Declaration of Helsinki adopted in 1975 and revised in 2008 , and the ethical principles were entirely respected.

\section{References}

1. Gorkhali B, Sharma S, Amatya M, Acharya D, Sharma M Anxiety and depression among patients with thyroid function disorders. J Nepal Health Res Counc. 2020;18(3):373-8. https:// doi.org/10.33314/jnhrc.v18i3.2499

PMid:33210626

2. Cohen BM, Sommer BR, Vuckovic A. Antidepressant-resistant depression in patients with comorbid subclinical hypothyroidism or high-normal TSH levels. Am J Psychiatry. 2018;175(7):598604. https://doi.org/10.1176/appi.ajp.2017.17080949

PMid:29961367

3. Ittermann T, Völzke H, Baumeister SE, Appel K, Grabe HJ. Diagnosed thyroid disorders are associated with depression and anxiety. Soc Psychiatry Psychiatr Epidemiol. 2015;50(9):141725. https://doi.org/10.1007/s00127-015-1043-0 PMid:25777685

4. Sharma AN, da Costa e Silva BF, Soares JC, Carvalho AF Quevedo J. Role of trophic factors GDNF, IGF-1 and VEGF in major depressive disorder: A comprehensive review of human studies. J Affect Disord. 2016;197:9-20. https://doi. 
org/10.1016/j.jad.2016.02.067

\section{PMid:26956384}

5. Lindholm JS, Castrén E. Mice with altered BDNF signaling as models for mood disorders and antidepressant effects. Front Behav Neurosci. 2014;8:143. https://doi.org/10.3389/ fnbeh.2014.00143

PMid:24817844

6. Krysiak R, Kowalcze K, Okopień B. The impact of exogenous Vitamin $D$ on thyroid autoimmunity in euthyroid men with autoimmune thyroiditis and early-onset androgenic alopecia. Pharmacol Rep. 2021;73(5):1439-47. https://doi.org/10.1007/ s43440-021-00295-3

PMid:34106452

7. Erensoy $\mathrm{H}$. The association between anxiety and depression with $25(\mathrm{OH}) \mathrm{D}$ and thyroid stimulating hormone levels. Neurosciences (Riyadh). 2019;24(4):290-5. https://doi. org/10.17712/nsj.2019.4.20190028

PMid:31872808

8. Mundo E, Tharmalingham S, Neves-Pereira M, Dalton EJ, Macciardi F, Parikh SV, et al. Evidence that the N-methyl-Daspartate subunit 1 receptor gene (GRIN1) confers susceptibility to bipolar disorder. Mol Psychiatry. 2003;8(2):241-5. https://doi. org/10.1038/sj.mp.4001218

PMid:12610658

9. Saito T, Chiba Y, Abe K, Hattori S, Katsuse O, Takahashi Y, et al. An investigative study of antibodies to NMDA-type glutamate receptor subunits in serum and cerebrospinal fluid in psychiatric patients with anti-thyroid antibodies. Helion. 2020;6(12):e05677. https://doi.org/10.1016/j.heliyon.2020.e05677 PMid:33319115

10. Degen AS, Krynytska IY, Kamyshnyi AM. Changes in the transcriptional activity of the entero-insular axis genes in streptozotocin-induced diabetes and after the administration of TNF- $\alpha$ non-selective blockers. Endocr Regul. 2020;54(3):160-71. https://doi.org/10.2478/enr-2020-0019 PMid:32857721

11. Nosulenko IS, Voskoboynik OY, Berest GG, Safronyuk SL, Kovalenko SI, Kamyshnyi OM, et al. Synthesis and antimicrobial activity of 6-thioxo-6, 7-dihydro-2H-[1, 2, 4] triazino [2, 3-c]-quinazolin-2-one derivatives. Sci Pharm. 2014;82(3):483-500. https://doi.org/10.3797/scipharm.1402-10 PMid:25853063

12. Putilin DA, Evchenko SY, Fedoniuk LY, Tokarskyy OS, Kamyshny OM, Migenko LM, et al. The influence of metformin to the transcriptional activity of the mTOR and FOX3 genes in parapancreatic adipose tissue of streptozotocin-induced diabetic rats. J Med Life. 2020;13(1):50-5. https://doi.org/10.25122/ jml-2020-0029

PMid:32341701

13. Dzhuryak V, Sydorchuk L, Sydorchuk A, Kamyshnyi O, Kshanovska A, Levytska $S$, et al. The cytochrome 11B2 aldosterone synthase gene CYP11B2 (RS1799998) polymorphism associates with chronic kidney disease in hypertensive patients. Biointerface Res Appl Chem. 2020;10(3):5406-11.

14. Lyubomirskaya ES, Kamyshnyi AM, Krut YY, Smiianov VA, Fedoniuk LY, Romanyuk LB, et al. SNPs and transcriptional activity of genes of innate and adaptive immunity at the maternal-fetal interface in woman with preterm labour, associated with preterm premature rupture of membranes. Wiad Lek. 2020;73(1):25-30

PMid:32124801

15. Bilous II, Pavlovych LL, Kamyshnyi AM. Primary hypothyroidism and autoimmune thyroiditis alter the transcriptional activity of genes regulating neurogenesis in the blood of patients. Endocr
Regul. 2021;55(1):5-15. https://doi.org/10.2478/enr-2021-0002 PMid:33600668

16. Kamyshna I, Kamyshnyi A. Transcriptional activity of neurotrophins genes and their receptors in the peripheral blood in patients with thyroid diseases in Bukovinian population of Ukraine. Open Access Maced J Med Sci. 2021;9(A):208-16. https://doi.org/10.3889/oamjms.2021.6037

17. Bilous II, Korda MM, Krynytska IY, Kamyshnyi AM. Nerve impulse transmission pathway-focused genes expression analysis in patients with primary hypothyroidism and autoimmune thyroiditis. Endocr Regul. 2020;54(2):109-18. https://doi.org/10.2478/enr-2020-0013

PMid:32597152

18. Bilous I, Pavlovych L, Krynytska I, Marushchak M, Kamyshnyi A. Apoptosis and cell cycle pathway-focused genes expression analysis in patients with different forms of thyroid pathology. Open Access Maced J Med Sci. 2020;8(B):784-92. https://doi. org/10.3889/oamjms.2020.4760

19. Kamyshna I, Pavlovych L, Kamyshnyi A. Association between serum brain-derived neurotrophic factor and 25-OH Vitamin D levels with Vitamin D receptors gene polymorphism (rs2228570) in patients with autoimmune thyroiditis and hypothyroidism. Open Access Maced J Med Sci. 2021;9(A):659-64. Available from: https://www.oamjms.eu/index.php/mjms/article/view/6631 [Last accessed on 2021 Oct 07].

20. Kamyshna I, Pavlovych L, Malyk I, Kamyshnyi A. 25-OH Vitamin D blood serum linkage with VDR gene polymorphism (rs2228570) in thyroid pathology patients in the West-Ukrainian population. J Med Life. 2021;14(4):549-56.

21. Kamyshna I, Pavlovych L, Maslyanko V, Kamyshnyi A. Analysis of the transcriptional activity of genes of neuropeptides and their receptors and their receptors in the blood of patients with thyroid pathology. J Med Life. 2021;14(2):243-9. https://doi. org/10.25122/jml-2020-0183

PMid:34104248

22. Kamyshna I, Pavlovych L, Sydorchuk L, Malyk I, Kamyshnyi A BDNF blood serum linkage with BDNF gene polymorphism (rs6265) in thyroid pathology patients in the West-Ukrainian population. Endocr Regul. 2021;55(4):101-11. https://doi. org/10.2478/enr-2021-0021

PMid:34879183

23. Garber JR, Cobin RH, Gharib H, Hennessey JV, Klein I, Mechanick Jl, et al. Clinical practice guidelines for hypothyroidism in adults: Cosponsored by the American association of clinical endocrinologists and the American thyroid association. Endocr Pract. 2012;18(6):988-1028. https://doi.org/10.4158/EP12280.GL PMid:23246686

24. Blacker D. Rating scales in psychiatry. In: Sadock BJ, Sadock VA editors. Comprehensive Textbook of Psychiatry. $8^{\text {th }}$ ed. Philadelphia, PA: Lippincott Williams \& Wilkins; 2007. p. 929-43.

25. Leyhe T, Müssig K. Cognitive and affective dysfunctions in autoimmune thyroiditis. Brain Behav Immun. 2014;41:261-6. https://doi.org/10.1016/j.bbi.2014.03.008 PMid:24685840

26. Siegmann EM, Müller HH, Luecke C, Philipsen A, Kornhuber J Grömer TW. Association of depression and anxiety disorders with autoimmune thyroiditis: A systematic review and metaanalysis. JAMA Psychiatry. 2018;75(6):577-84. https://doi. org/10.1001/jamapsychiatry.2018.0190 PMid:29800939

27. Kim EY, Kim SH, Rhee SJ, Huh I, Ha K, Kim J, et al. Relationship between thyroid-stimulating hormone levels and risk of depression among the general population with normal free T4 levels. Psychoneuroendocrinology. 2015;58:114-9. https://doi. org/10.1016/j.psyneuen.2015.04.016

PMid:25973566 
28. Panicker V, Evans J, Bjøro T, Åsvold BO, Dayan CM, Bjerkeset $\mathrm{O}$. A paradoxical difference in relationship between anxiety, de-pression and thyroid function in subjects on and not on T4: Findings from the HUNT study. Clin Endocrinol (Oxf). 2009;71(4):574-80. https://doi.org/10.111 $1 / \mathrm{j} .1365-2265.2008 .03521$ PMid:19751298

29. Fukao A, Takamatsu J, Kubota S, Miyauchi A, Hanafusa T. The thyroid function of Graves' disease patients is aggravated by depressive personality during antithyroid drug treatment. Biopsychosoc Med. 2011;5:9. https://doi. org/10.1186/1751-0759-5-9

PMid:21827669

30. Bárez-LópezS, Montero-PedrazuelaA,Bosch-GarcíaD, Venero C, Guadaño-Ferraz A. Increased anxiety and fear memory in adult mice lacking Type 2 deiodinase. Psychoneuroendocrinology. 2017;84:51-60. https://doi.org/10.1016/j.psyneuen.2017.06.013 PMid:28654773

31. Duman RS, Monteggia LM. A neurotrophic model for stressrelated mood disorders. Biol Psychiatry. 2006;59(12):1116-27. https://doi.org/10.1016/j.biopsych.2006.02.013 PMid:16631126

32. Allen AP, Naughton M, Dowling J, Walsh A, Ismail F, Shorten G, et al. Serum BDNF as a peripheral biomarker of treatment-resistant depression and the rapid antidepressant response: A comparison of ketamine and ECT. J Affect Disord. 2015;186:306-11. https://doi.org/10.1016/j.jad.2015.06.033 PMid:26275358

33. Neto FL, Borges G, Torres-Sanchez S, Mico JA, Berrocoso E. Neurotrophins role in depression neurobiology: A review of basic and clinical evidence. Curr Neuropharmacol. 2011;9(4):530-52. https://doi.org/10.2174/157015911798376262

PMid:22654714

34. Masi G, Brovedani P. The hippocampus, neurotrophic factors and depression possible implications for the pharmacotherapy of depression. Cns Drugs. 2011;25(11):913-31. https://doi. org/10.2165/11595900-000000000-00000 PMid:22054117

35. Fu X, Wang J, Du J, Sun J, Baranova A, Zhang F. BDNF Gene's role in schizophrenia: From risk allele to methylation implications. Front Psychiatry. 2020;11:564277. https://doi. org/10.3389/fpsyt.2020.564277

PMid:33384622

36. Egan MF, Kojima M, Callicott JH, Goldberg TE, Kolachana BS, Bertolino $A$, et al. The BDNF val66met polymorphism affects activity-dependent secretion of BDNF and human memory and hippocampal function. Cell. 2003;112(2):257-69. https://doi. org/10.1016/s0092-8674(03)00035-7

PMid:12553913
37. Notaras $M$, van den Buuse $M$. Brain-derived neurotrophic factor (BDNF): Novel insights into regulation and genetic variation. Neuroscientist. 2019;25(5):434-54. https://doi. org/10.1177/1073858418810142

PMid:30387693

38. Gallinat J, Schubert F, Brühl R, Hellweg R, Klär AA, Kehrer C, et al. Met carriers of BDNF Val66Met genotype show increased $\mathrm{N}$-acetylaspartate concentration in the anterior cingulate cortex. Neuroimage. 2010;49(1):767-71. https://doi.org/10.1016/j. neuroimage.2009.08.018 PMid:19683059

39. Bath KG, Jing DQ, Dincheva I, Neeb CC, Pattwell SS, Chao MV, et al. BDNF Val66Met impairs fluoxetine-induced enhancement of adult hippocampus plasticity. Neuropsychopharmacology. 2012;37:1297-304. https://doi.org/10.1038/npp.2011.318 PMid:22218094

40. Lang UE, Hellweg R, Sander T, Gallinat J. The met allele of the BDNF Val66Met polymorphism is associated with increased BDNF serum concentrations. Mol Psychiatry. 2009;14(2):120-2. https://doi.org/10.1038/mp.2008.80

PMid:19156154

41. Hoogendijk WJ, Lips P, Dik MG, Deeg DJ, Beekman AT, Penninx BW. Depression is associated with decreased 25-hydroxyvitamin $D$ and increased parathyroid hormone levels in older adults. Arch Gen Psychiatry. 2008;65(5):508-12. https:// doi.org/10.1001/archpsyc.65.5.508

PMid:18458202

42. Talaei A, Ghorbani F, Asemi Z. The effects of Vitamin D supplementation on thyroid function in hypothyroid patients: A randomized, double-blind, placebo-controlled trial. Indian $\mathrm{J}$ Endocrinol Metab. 2018;22(5):584-8. https://doi.org/10.4103/ ijem.ijem_603_17 PMid:30294564

43. Mackawy AM, Al-Ayed BM, Al-Rashidi BM. Vitamin d deficiency and its association with thyroid disease. Int $\mathrm{J}$ Health Sci (Qassim). 2013;7(3):267-75. https://doi.org/10.12816/0006054 PMid:24533019

44. Carta MG, Hardoy MC, Carpiniello B, Murru A, Marci AR, Carbone $\mathrm{F}$, et al. A case control study on psychiatric disorders in Hashimoto disease and Euthyroid Goitre: Not only depressive but also anxiety disorders are associated with thyroid autoimmunity. Clin Pract Epidemiol Ment Health. 2005;1:23. https://doi.org/10.1186/1745-0179-1-23 PMid:16285879

45. Kirim S, Keskek SO, Köksal F, Haydardedeoglu FE, Bozkirli’ E, Toledano Y. Depression in patients with euthyroid chronic autoimmune thyroiditis. Endocr J. 2012;59(8):705-8. https://doi. org/10.1507/endocrj.ej12-0035

PMid:22673294 